\title{
Correlation of Nutrition Discovering and Nutritional Status on Students' Achievement at SMP Negeri SATAP 2 Sausu
}

\author{
Abd. Hakim Laenggeng \\ Universitas Tadulako \\ Palu, Indonesia \\ ah.laenggeng@yahoo.co.id \\ Amram Rede \\ Universitas Tadulako \\ Palu, Indonesia \\ amramrede@yahoo.co.id
}

\author{
Hasnawati \\ Universitas Tadulako \\ Palu, Indonesia
}

\begin{abstract}
This study aimed to 1) describe correlation of nutrition discovering and student's achievement, 2) describe correlation of nutritional status and student's achievement, 3) describe correlation both nutritional discovering and nutritional status toward student's achievement. This study was descriptive research by the quantitative approach in 42 students as a sample. The data collecting by using questionnaire, mass index body, and book report of students. They were analyzed by correlation product moment person with aid SPSS. The result of the analysis showed that correlation between nutritional discovering and students achievement obtained 0.227 , they might interpret there was low correlation because in the range 0.20-0.399. Moreover, the result of the correlation between nutrition status and student's achievement obtained 0.377 by interpreted also a low correlation, where $R=0.468$ and value of $F$ count $=5.465$ and $\mathrm{Ftab}=0.008$ by interpreted there was a moderate correlation between nutritional discovering and nutrition status with student's achievement.
\end{abstract}

Keywords: Nutrition Discovering, Nutrition Status, Students Achievement.

\section{INTRODUCTION}

Nutrition knowledge is capable of choosing foods that are the source of nutrients and capability in choosing healthy snacks [1]. Nutrition status affected to the intelligence level of a person and the ability of a person to catch a lesson in school, so someone who has good nutritional status will have better capture ability and can get good achievement also in school. Conversely, if a person has a nutritional status that is less or more will affect the intelligence so less optimal in capturing knowledge in school and learning achievement becomes less good. Printing healthy and intelligent generation should start from fetus to teenage children, interventions should be given to children especially in terms of nutrition, health, and education [2].
Student achievement is the result of measuring cognitive, affective and psychomotor factors after following the learning process. Learning achievement can be measured through tests that are often known as achievement tests. Cognitive intelligence is closely related to one's nutritional status [3].

Attention nutrition in adolescents is a response based on how much nutrition knowledge and how big the skills in doing nutrition practice. Improper attention nutritional can be altered through nutritional learning. Efforts to learn nutrition in teenagers more effectively done in schools, especially junior high school students because it is in the period of rapid growth after the toddler. Nutrition learning is expected to be one solution to improve the nutritional status and health status of adolescents.

SMP Negeri Satu Atap (SATAP) 2 Sausu is located in Sausu Pakareme Village, Sausu District, Parigi Moutong District. The school is located about $\pm 7 \mathrm{~km}$ from Jalan Trans Sulawesi and $120 \mathrm{~km}$ from Palu City which has 52 students divided into class VII as many as 10 people, class VIII as many as 22 people and class IX as many as 20 people. Among the 4 (four) SATAP Junior High Schools in Parigi Moutong District, this school has the highest number of students.

Based on observations and interviews with the principal of SMP Negeri SATAP 2 Sausu, there are some things that underlie to do research in the school, namely: The school is located in rural areas with schools that are not equipped with support facilities such as internet connection area so that students difficult to add knowledge. Subject to the nutritional status of students from the observation, showing the condition of thin, normal and heterogeneous (as well as the minimum grade of completeness for all subjects of class VII-IX vary in the sense that there are still students whose learning achievement is less good.

Based on the description above the author is interested to describe the relationship of nutritional knowledge with student 
achievement, describe the relationship of nutritional status with student achievement, and describe the relationship of nutritional knowledge and nutritional status with student achievement.

\section{METHODS}

This article is adapted from the research results. This research type includes descriptive research with a quantitative approach, that is an effort to measure independent variable and dependent variable. The research location is SMP Negeri SATAP 2 Sausu, Sausu District, Parigi Moutong District. The time of the study was conducted from July to August 2016.

\section{A. Population and Sample}

The population in this research is all students of SMP Negeri SATAP 2 Sausu that is class VII students as many as 10 people, class VIII as much 22 person and students of class IX as many as 20 people. So, the total number of students is 52 person. The sample of this study is a sample of a portion of the population consisting of classes VIII and IX that is as much as 42 person. In this case, the students of class VII are not taken as research samples because of the new school year so that students do not have the learning achievement (report card).

\section{B. Data collection technique}

\section{1) Observation}

Observation is Collecting initial data that exist in school in the form of situation or condition of School and the number of students of SMP Negeri SATAP 2 Sausu.

\section{2) Questionnaire}

Instruments used in data collection by giving or distributing a list of questions that have been validated then given to the respondent. This technique is used to find out how the students nutritional knowledge.

\section{3) Measurement of Nutrition Status}

Measurement of nutritional status of body weight and adolescent height in this study was obtained by measuring the anthropometric index and measured by WHO standard. The formula is:

$$
\text { IMT }=\frac{\text { Berat Badan }(\mathrm{kg})}{\text { Tinggi Badan }(\mathrm{m}) \times \text { Tinggi Badan }(\mathrm{m})}
$$

Data collection techniques conducted in this study are:

\section{Measurement of Learning Achievement}

Measurement of learning achievement by looking at student report cards, for 2 semesters (even semesters).

\section{Data Analysis Technique}

The relationship between independent variables with the dependent variable, then used multiple correlation analysis with the equation as follows:

$$
\operatorname{Ry} x 1 \times 2=\sqrt{\frac{r y x 1+r y \times 2-2 r y \times 1 r y \times 2 r \times 1 \times 2}{1-r^{2} \times 1 \times 2}}
$$

Where:

Ry.x1 x2 = Correlation between variables X1 with X2 together with variable Y.

Ryx 1 = Product Moment Correlation between X1 and Y. Ryx 2 = Product Moment Correlation between X2 and Y. $\mathrm{Rx} 1 \mathrm{x} 2$ = Product Moment Correlation between X1 and X.

TABLE II. GUIDELINES FOR GIVING INTERPRETATION OF CORRELATION COEFFICIENTS.

\begin{tabular}{|c|c|}
\hline Coefficient Interval & Relationship Level \\
\hline $0,00-0,199$ & Very low \\
\hline $0,20-0,39$ & Low \\
\hline $0,40-0,599$ & Medium \\
\hline $0,60-0,799$ & Strong \\
\hline $0,80-1,000$ & Very strong \\
\hline
\end{tabular}

Tests on multiple correlation coefficients can use the following formula by $\mathrm{F}$ test and the results are compared with

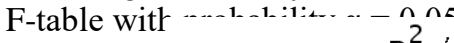

$$
F h=\frac{R^{2} / K}{\left(1-R^{2}\right) /(n-k-1)}
$$

Where

$\mathrm{R}=$ Double correlation coefficient

$\mathrm{K}=$ Number of independent variables

$\mathrm{N}=$ Number of Sample

In order to facilitate the data analysis used data analysis techniques using computer programs.

\section{RESULTS AND DISCUSSION}

TABLE I. IMT LIMIT THRESHOLD CATEGORY FOR INDONESIA

\begin{tabular}{|c|c|c|}
\hline Nutritional Status & Characteristic & IMT \\
\hline Thin & $\begin{array}{c}\text { Too Loss Weight } \\
\text { Lack of Light Weight Loss }\end{array}$ & $<17,0-18,5$ \\
& Excess Light Weight Level & $>25,0-25,0$ \\
\hline Normal & Excess High Weight & $>27,0$ \\
\hline Fat &
\end{tabular}

\section{A. Results}

The correlation between variables can be seen in the following table.

\begin{tabular}{|c|c|c|}
\hline Variable & Correlation (r) & Category \\
\hline $\mathrm{X}_{1} \mathrm{Y}$ & 0.277 & Low \\
\hline $\mathrm{X}_{2} \mathrm{Y}$ & 0.377 & Low \\
\hline $\mathrm{X}_{1} \mathrm{X}_{2} \mathrm{Y}$ & 0.468 & Medium \\
\hline
\end{tabular}


1) Knowledge Relations and Nutrition Status with Learning Achievement

Nutrition is a major determinant of the quality of human resources, the nutritional status of good students will produce a good degree of health and a good level of intelligence as well. Correlation analysis performed with Product Moment Pearson using computer program result of correlation test obtained that is 0,227 with the interpretation that there is a low correlation between knowledge of nutrition with learning achievement because its value is at interval $0,20-0,399$. Good nutrition knowledge of a person can support in terms of healthy and balanced food selection so that it can affect the determination of the nutritional status of students who will also affect the learning achievement.

2) Relationship of Nutrition Status with Learning Achievement

Sufficient nutritional status is important for health and welfare and nutrition provides facts that need attention so that people can learn to use food well for nutritional improvement. Correlation analysis used is Product Moment Pearson with correlation test results obtained 0.377 with the interpretation that there is a low relationship between nutritional knowledge with learning achievement because the value is at interval 0.20 - 0.399. A good nutritional status will affect the growth process and development of students one of them can improve intellectual ability that will impact on student achievement.

3) Knowledge Relation and Nutritional Status with Learning Achievement.

The results of data analysis conducted in finding the relationship between nutritional knowledge and nutritional status with learning achievement obtained R-value or correlation coefficient is 0.468 this value can be interpreted that the relationship between the two research variables included in the category of being and the value of R Square or coefficient of determination obtained is 0.219 shows That knowledge and nutritional status contribute to moderate learning achievement. So, it can be seen that Fcount is 5,465 when compared with Ftable with probability $(\alpha=0,05)$ got $F_{\text {tabel }} 0,008$. Because of $F_{\text {count }}>F_{\text {tabel }}$, then $\mathrm{H}_{1}$ accepted and $\mathrm{H}_{0}$ rejected that there is a relationship between knowledge and nutritional status with student achievement of SMP Negeri SATAP 2 Sausu with the medium category.

\section{B. Discussion}

Nutrition knowledge is the versatility of choosing foods that are a source of nutrients and ingenuity in choosing good snack foods. The impact of these errors is not only felt instantly after we consume certain foods, but it could also be the impact it appears after we consume food for long periods of time. Junior high school students are teenagers, is the most important phase of the process of human growth and development, the condition of a person in adulthood is determined by the state of nutrition and health in adolescence. The results of correlation test in this study between nutritional knowledge with learning achievement show relationship with the low category. Based on the result of the research which is compared with previous research done by [4], there is a very low correlation between nutrition knowledge and attitude of choosing food snack with nutritional status of students of SMP Negeri 1 Palu.

While externally is the knowledge that comes from outside or from others or information obtained from the mass media and come from the environment that can indirectly affect the knowledge of the child itself. In this study, the questionnaire used by researchers is only a question that includes general knowledge gained in education level. Based on this research that most of nutrition knowledge of student is good enough this matter influenced by facility at school such as the existence of book provided in school library although still less and the material still basics only and information from subject teacher of IPA and Penjas so that enable student earn Information in teaching and learning process and the most important is the interest and motivation from within the student to follow the lessons given by the teacher.

Nutrition status describes the state of a person's nutritional balance and can be used as an indicator of someone in more nutritional conditions, less and normal. To determine the nutritional status can be done with various ways, based on the results of research on the measurement of the nutritional status of students in SMP Negeri SATAP 2 Sausu used is BMI index with the formula BB $(\mathrm{kg}) / \mathrm{TB}(\mathrm{m}) \mathrm{x}$ TB $(\mathrm{m})$. The formula is used because it is tailored to the age of students who fall into the category of adolescents. Learning achievement is the level of success of students in learning the subject matter in school expressed in the form of scores obtained from test results on a number of specific subject matter. To know student achievement is done by using evaluation every end of the semester, in this case, the researcher to see student achievement on the value of report card. Indirectly if the knowledge of good nutrition then the nutritional status of a person will also be good that will have an impact on the achievement of learning is also good. The results of correlation test in this study between nutritional status with learning achievement shows relationship with low category, it can be said that the nutritional problems in the students in SMP Negeri SATAP 2 Sausu still classified in the light stage so it is not too disturbing the learning ability, therefore the test results the correlation obtained is said to be low. The results of this study are in line with previous research conducted by [5], the results of his research indicate that there is a relationship between the nutritional status of students SDN 3 Ogomoli Galang District Tolitoli District with student achievement, although the level of relationship is very low.

A good nutritional intake plays an important role in achieving optimal body growth. This optimal body growth includes brain growth that determines a person's intelligence. The final impact of good and balanced nutrition consumption is the increasing quality of human resources. The state of nutritional status and the achievement index is a picture of what students consumed in the long term, can be less nutrition or more nutrition. Nutrients such as carbohydrates, proteins, and other nutrients, especially iron, in the body's metabolism play a role in the thinking process or the process of reasoning and the power of concentration and are closely related to the efficiency of learning. Ref. [6] suggested that good nutrition status will affect the process of growth and development of 
students one of which can improve intellectual ability that will impact on school achievement.

Broadly speaking, the factors that influence the success of learning can be divided into two major parts of internal and external factors. Internal factors are factors derived from within the individual itself consists of biological factors and psychological factors, nutritional status is also influenced by the intake of carbohydrates, energy, protein, fat and other nutrients.

Based on the results of research conducted by using Product Moment Pearson by using SPSS Application with correlation test obtained the interpretation that there is a moderate relationship between nutritional knowledge and nutritional status with student achievement of SMP Negeri SATAP 2 Sausu, because of Fcount $>$ Ftabel, then H1 accepted and $\mathrm{H} 0$ rejected.

Based on the result of the research, it is found that in relation with the previous research, it is in accordance with the research conducted by [7], that there is a positive correlation between nutritional status and health with student achievement level.

\section{CONCLUSION}

Based on the results of research and data analysis can be concluded that:

1. The correlation test results between nutritional knowledge with learning achievement are 0.227 with the interpretation that there is a low relationship between the two.

2. The correlation test results between nutritional status with learning achievement are 0.377 with the interpretation that there is a low relationship between the two.

3. Based on the results of research tests conducted using Product Moment Pearson using SPSS application is an obtained value $(\mathrm{R}=0.468)$. And the correlation value obtained is the value of Fhitung $=5,465$ and Ftabel $=$ 0.008 with the interpretation that there is a moderate relationship between knowledge and nutritional status with student achievement of SMP Negeri SATAP 2 Sausu, because of Fcount $>$ Ftabel, then H1 accepted and $\mathrm{H} 0$ rejected.

\section{REFERENCE}

[1] Notoatmodjo,S. (2003). Ilmu Kesehatan Masyarakat (Prinsip- prinsip Dasar). Jakarata: PT. Rineka Cipta.

[2] Khomsan, A. (2004). Pengantar Pangan dan Gizi. Jakarta: Penebar Swadaya.

[3] Hardinsyah. (2007). Inovasi dan Pengembangan Modal Sosial bagi Peningkatan Kualitas Hidup Manusia dan Pengentasan Kemiskinan. Bogor: Orasi Ilmiah pada FEM IPB.

[4] Lumalan, Y. (2012). Hubungan Pengetahuan Gizi dan Sikap Memilih Makanan Jajanan dengan Status Gizi Siswa SMP Negeri 1 Palu. Skripsi Sarjana pada FKIP UNTAD Palu: tidak diterbitkan.

[5] Iqbal, M. (2012). Hubungan Status Gizi dengan Prestasi Belajar Siswa SDN 3 Ogomoli Kecamatan Galang Kabupaten Tolitoli. Palu: Skripsi pada Sarjana UNTAD tidak diterbitkan.
[6] Ridwan dan Sunarto. (2009). Pengantar Statistika untuk Penelitian. Bandung: Alfabeta.

[7] Maryam. (2001). Status Gizi, Peer Group dan Aktifitas Harian serta Kaitannya dengan Prestasi Belajar Remaja (Studi Kasus pada Dua SMU di Kota Bogor). Skripsi Sarjana pada Institut Pertanian Bogor: tidak diterbitkan. 